\title{
New Genes for Leaf Rust Resistance in CIMMYT Durum Wheats
}

\author{
S. A. Herrera-Foessel, Dept. of Ecology and Crop Production Sciences, Swedish University of Agricultural Sci- \\ ences (SLU), Box 7043, S 75007 Uppsala, Sweden; R. P. Singh, International Maize and Wheat Improvement Cen- \\ ter (CIMMYT), Apdo. Postal 6-641, 06600 México, D.F., México; J. Huerta-Espino, Campo Experimental Valle de \\ México INIFAP, Apdo. Postal 10, 56230, Chapingo, Edo de México, México; and J. Yuen and A. Djurle, Dept. of \\ Ecology and Crop Production Sciences, Swedish University of Agricultural Sciences (SLU), Box 7043, S 75007 \\ Uppsala, Sweden
}

\begin{abstract}
Herrera-Foessel, S. A., Singh, R. P., Huerta-Espino, J., Yuen, J., and Djurle, A. 2005. New genes for leaf rust resistance in CIMMYT durum wheats. Plant Dis. 89:809-814.

Leaf rust, caused by Puccinia triticina, has become an important disease of durum wheat (Triticum turgidum) in Mexico since the detection in 2001 of BBG/BN, a new race virulent on all common cultivars and on more than $80 \%$ of CIMMYT's durum wheat collection. We investigated the genetic basis and diversity of resistance in nine durum genotypes that are highly resistant to the new race. These resistant durums were crossed with the susceptible cv. Atil C2000 and intercrossed in a half diallel arrangement. Five diverse sources of resistance were identified by evaluating parents, $F_{1}, F_{2}$, and $F_{3}$ populations in greenhouse and/or field trials under artificial epidemics of race BBG/BN. The same pair of partially dominant complementary genes determined resistance in Jupare C2001, Hualita, and Pohowera. Somateria and Llareta INIA shared the same dominant resistance gene, whereas a partially dominant gene conferred resistance in two sister lines, Guayacan 2 and Guayacan INIA. A different partially dominant gene present in Storlom was linked in repulsion to another partially dominant gene in Camayo. These diverse resistance genes can be used effectively to control leaf rust, preferably by deploying them in combinations.
\end{abstract}

Additional keywords: brown rust, genetic analysis, inheritance study, Puccinia recondita f. sp. tritici, Triticum turgidum var. durum

Durum wheat (Triticum turgidum L. var. durum) is grown on approximately 17 million hectares worldwide. Leaf rust caused by Puccinia triticina Eriks. is an important disease that causes significant durum production losses. In Mexico, durum wheat remained highly resistant to leaf rust until 2001, when a new race, designated $\mathrm{BBG} / \mathrm{BN}$, was detected (23). Over $80 \%$ of the entire CIMMYT durum wheat collection and the most popular Mexican cultivar, Altar C84, which had remained resistant for 16 years, proved susceptible to the new race. Altar C84 and several other breeding lines carried the same partially dominant seedling resistance gene that conferred resistance to race $\mathrm{BBB} / \mathrm{BN}$, prevalent on durum wheat in Mexico during the 1980s and 1990s (22). These cultivars also carried one or two additional minor genes for slow rusting resistance in adult plants. The gene that conferred seedling resistance to race $\mathrm{BBB} / \mathrm{BN}$ in Altar

Corresponding author: S. A. Herrera-Foessel

E-mail: sybil.herrera@evp.slu.se

Accepted for publication 10 March 2005.

DOI: 10.1094/PD-89-0809

(C) 2005 The American Phytopathological Society
C84 and other CIMMYT durums remains undesignated. The leaf rust epidemics on durum wheat during 2001, 2002, and 2003, caused by the new race BBG/BN, resulted in estimated losses of about US\$32 million to Mexican farmers (23).

Although durum wheat showed high susceptibility to the new race in Mexico, bread wheat cultivars in neighboring fields were not affected. Previous reports have revealed differences in virulence specificity of leaf rust races isolated from durum and bread wheat. In 1988 and 1989, Singh (20) studied the pathogenic variation of leaf rust in wheat-growing areas of Mexico and found that race $\mathrm{BBB} / \mathrm{BN}$ predominated in durum wheat collections, while races TCB/TD and TBD/TM predominated on bread wheat. Huerta-Espino and Roelfs (5) compared leaf rust collections taken globally from durum and bread wheats and reported that races isolated from durum wheat differed in virulence from those collected from bread wheat. The leaf rust isolates collected from durum wheat were avirulent to most of the near-isogenic Thatcher lines used as differentials, suggesting that these lines may not be the most useful in differentiating the durum leaf rust races. Recently, Ordonez et al. (11) also indicated a high degree of avirulence for known leaf rust resistance genes in leaf rust populations collected in France, Spain, Ethiopia, the United States, Mexico, Chile, and Argentina. Furthermore, their results revealed a high degree of similarity in avirulence-virulence characteristics of races from Europe, South and North America, and Mexico.

Compared with bread wheat, little is known regarding leaf rust resistance in durum wheat. Of the 50 designated resistance genes in wheat, only two, $L r 14 a$ and Lr23, originated from tetraploid wheat. The acreage in developing countries that is sown to CIMMYT-derived durum wheats (i.e., those with at least one CIMMYT parent) accounts for a major part of the total durum area (13). Increased knowledge of the genetic basis of resistance that is effective against the new Mexican race $(\mathrm{BBG} / \mathrm{BN})$ is of high importance to enhance the genetic diversity of resistance in CIMMYT germ plasm and future durum wheat cultivars. Following the detection of the $\mathrm{BBG} / \mathrm{BN}$ race in Mexico, sources of resistance were identified after screening thousands of germ plasm lines from the CIMMYT durum wheat-breeding program.

The objective of our study was to determine the genetic basis and genetic diversity of resistance in nine durum wheat genotypes that are resistant to Mexican $P$. triticina race $\mathrm{BBG} / \mathrm{BN}$.

\section{MATERIALS AND METHODS}

The nine resistant durum wheat parents included in the study were Jupare C2001, Hualita, Pohowera, Somateria, Llareta INIA, Camayo, Storlom, Guayacan 2, and Guayacan INIA. The susceptible durum wheat parent was Atil C2000. Pedigrees and selection history of each of the durum wheats are listed in Table 1. Jupare C2001, released in 2001, is the most commonly grown Mexican cultivar. Both Llareta INIA and Guayacan INIA were released in Chile in $1997(14,15)$. Other parents are advanced CIMMYT breeding lines. Atil C2000, the susceptible parent, was released for cultivation in Mexico in 2000 but proved susceptible to race BBG/BN.

The resistant parents were crossed with the susceptible Atil C2000 and also intercrossed in a half-diallel arrangement, i.e., in all possible combinations without the reciprocals. Space-sown $F_{1}$ plants were harvested individually to obtain $\mathrm{F}_{2}$ prog- 
eny. For each susceptible $\times$ resistant cross, approximately $98 \mathrm{~F}_{3}$ lines were obtained by harvesting space-sown individual $F_{2}$ plants derived from two different $F_{1}$ plants. Genetic analysis was based on the leaf rust response data for parents, $F_{1}$ plants, $F_{2}$ populations, and $\mathrm{F}_{3}$ families, and was conducted in the field at CIMMYT's research station in El Batán, Mexico, during 2003. The parents and the $F_{1}$ of the resistant $x$ susceptible crosses were also evaluated in the greenhouse for infection type responses at both seedling and adult plant stages.

The $P$. triticina race $\mathrm{BBG} / \mathrm{BN}$ used in this study has the following avirulencevirulence formula (23): $\operatorname{Lr} 1,2 a, 2 b, 2 c, 3$, $3 b g, 3 k a, 9,12,13,14 a, 15,16,17,18,19,21,24$, $25,26,27+31,28,29,30,32,34,35,36,37 / 10$, $11,14 b, 20,23,33$.

In greenhouse trials, the parents and $F_{1}$ plants from susceptible $\times$ resistant crosses were inoculated at the seedling (two-leaf stage) and adult plant stages (seven-leaf stage) by spraying urediniospores suspended in Soltrol 170, a light mineral oil, at a concentration of 2 to $3 \mathrm{mg} / \mathrm{ml}$. Plants were placed in a dew chamber overnight to ensure spore germination and completion of the infection process, and then transferred to a greenhouse kept at 18 to $25^{\circ} \mathrm{C}$. Infection types displayed by the leaves were recorded about 10 days after inoculation according to a 0 -to-4 scale (17).

The field trial was grown on $0.75-\mathrm{m}$ wide raised beds with paired rows $0.2 \mathrm{~m}$ apart. Approximately 60 seeds of parents and $\mathrm{F}_{3}$ lines were sown as 0.8 -m-long paired rows with 0.4-m alleys. Twelve $F_{1}$ plants were space-sown 10 to $15 \mathrm{~cm}$ apart in plots of the same size, and 50 to $100 \mathrm{~F}_{2}$ plants derived from three different $F_{1}$ plants were space-sown on three pairs of rows $5 \mathrm{~m}$ in length. This $\mathrm{F}_{2}$ planting arrangement allowed us to evaluate 150 to $300 \mathrm{~F}_{2}$ plants per cross. Spreaders of susceptible Atil C2000 were planted around the field and as hills in the middle of the pathway on one side of each plot. To initiate the disease epidemic, spreaders were inoculated on 18 June (about a month after planting) and 25 June 2003, using a handheld sprayer containing urediniospores suspended in Soltrol 170. Rust severity and host response to infection were recorded for the parents five times at weekly intervals starting on 15 July, when the flag leaves of Atil C2000 were fully expanded. Disease data for the $F_{1}, F_{2}$, and $F_{3}$ were recorded between 29 July and 2 August, the last date being when the susceptible parent Atil C2000 displayed a 100S response. Percent rust severity on flag leaves of parent, $F_{1}$, and $F_{2}$ plants was estimated using the modified Cobb scale (12). Host response to infection was recorded according to Roelfs et al. (17). Although some variation in percent severity was noted in a few crosses, for simplicity each $\mathrm{F}_{3}$ line was classified as homozygous resistant (HR), segregating (Seg), or homozygous susceptible (HS) based on reaction and severity. The comparison between the observed phenotypic distributions of segregating populations (in the $\mathrm{F}_{2}$ and $\mathrm{F}_{3}$ generations) and the expected ratio was performed by chi-squared $\left(\chi^{2}\right)$ tests.

\section{RESULTS}

Responses of the parents. Of the parents, only Atil C2000 displayed susceptible infection type responses in the green- house as seedling and as adult plant (Table 2 ). Five of the nine resistant parents displayed mesothetic infection types $\mathrm{X}-, \mathrm{X}$, or $\mathrm{X}+$ at the seedling stage. However, when evaluated as adult plants, the infection types of the parents were generally lower, except for Camayo, which displayed infection type $1+$ as seedling and $3 \mathrm{C}$ as adult plant. Storlom, the most resistant parent, displayed infection types ; at the seedling stage and 0 ; at the adult plant stage. In adult plant, the infection type for Jupare C2001 and Pohowera was ;1which was similar to infection type ;1 displayed by Guayacan 2 and Guayacan INIA. Both Hualita and Somateria displayed infection type $\mathrm{X}-$, which was similar to infection type $\mathrm{X}$ displayed by Llareta INIA. Seedling and adult plant infection type data thus indicated phenotypic diversity among parents.

In the field trial, the nine resistant parents showed high levels of resistance. When Atil C2000 displayed 100\% severity, five parents (Jupare C2001, Hualita, Pohowera, Somateria, and Storlom) were immune to leaf rust; Llareta INIA, Guay-

Table 2. Greenhouse and field responses of parents and $F_{1}$ plants from the crosses of susceptible parent Atil C2000 with nine resistant parents when inoculated with Puccinia triticina race BBG/BN

\begin{tabular}{|c|c|c|c|c|c|}
\hline \multirow[b]{3}{*}{ Parent } & \multicolumn{3}{|c|}{ Parental response } & \multicolumn{2}{|c|}{$F_{1}$ response } \\
\hline & \multicolumn{2}{|c|}{ Greenhouse $^{a}$} & \multirow[b]{2}{*}{ Field $^{b}$} & \multirow{2}{*}{$\begin{array}{c}\text { Greenhouse }^{\mathrm{a}} \\
\text { Adult }\end{array}$} & \multirow[b]{2}{*}{ Field $^{b}$} \\
\hline & Seedling & Adult & & & \\
\hline \multicolumn{6}{|l|}{ Resistant } \\
\hline Jupare C2001 & $\mathrm{X}_{-}$ & $; 1-$ & 0 & $3+$ & $30 \mathrm{M}$ \\
\hline Hualita & $X_{-}$ & $X_{-}$ & 0 & $3+$ & $5 \mathrm{MR}$ \\
\hline Pohowera & $\mathrm{X}$ & $; 1-$ & 0 & $3+$ & $5 \mathrm{MR}$ \\
\hline Somateria & $X+$ & $X_{-}$ & 0 & $X+3$ & 0 \\
\hline Llareta INIA & $3 \mathrm{C}$ & $\mathrm{X}$ & 1R-MR & $X+3$ & 1R-MR \\
\hline Camayo & $1+$ & $3 \mathrm{C}$ & $5-10 \mathrm{R}$ & $3 \mathrm{C}$ & $50 \mathrm{M}$ \\
\hline Storlom & ; & 0 & 0 & ; & $20 \mathrm{M}$ \\
\hline Guayacan 2 & $\mathrm{X}$ & $; 1$ & 1R-MR & $\mathrm{X}$ & $50 \mathrm{MS}$ \\
\hline Guayacan INIA & $; 1$ & $; 1$ & 1R-MR & $3 \mathrm{C} 3$ & $60 \mathrm{MS}$ \\
\hline \multicolumn{6}{|l|}{ Susceptible } \\
\hline Atil C2000 & $3+$ & $3+$ & $100 \mathrm{~S}$ & $3+$ & $100 \mathrm{~S}$ \\
\hline
\end{tabular}

a Infection types are based on a 0 -to- 4 scale (17), where $0=$ no uredinia or other macroscopic signs of infection, ; = no uredinia, but hypersensitive necrotic or chlorotic flecks of varying sizes present, $1=$ small uredinia surrounded by necrosis, $2=$ small to medium uredinia surrounded by green islands, $X$ $=$ random distribution of variable-sized uredinia on single leaf with a pure culture, 3 and $4=$ medium and large uredinia, respectively, without chlorosis or necrosis, + and $-=$ uredinia somewhat larger and smaller, respectively, than normal for infection type, $\mathrm{C}=$ more chlorosis than normal for the infection type. More than one designation represents a range of infection types.

${ }^{b}$ Field disease ratings have two components: disease severity and host response to infection. Severity follows the modified Cobb scale (12), and host response to infection are $\mathrm{R}=$ resistant, $\mathrm{MR}=$ moderately resistant, $\mathrm{MS}=$ moderately susceptible, $\mathrm{M}=\mathrm{MR}-\mathrm{MS}$, and $\mathrm{S}=$ susceptible (17).

Table 1. Pedigrees and selection histories of the Triticum turgidum parents included in the study

\begin{tabular}{lll}
\hline Parent & Cross & Selection history \\
\hline Jupare C2001 & Stinkpot//Altar 84/Alondra & CD91Y636-1Y-040M-030Y-1M-0Y-0B-1Y-0B \\
Hualita & Rascon_21/Longshanks & CDWS91M377-9M-030Y-030M-1Y-0M \\
Pohowera & Chen/Altar84//Hui/Tub/3/CMH82A.1062/Rissa & CD90226-501M-503YRC-502B-0Y \\
Somateria & Srn_1/6/Fgo/Dom//Nach/5/Altar84/4/Garza/Afn//Cra/3/Ggovz394/7/Eudo & CD89529-040PAP-030Y-040M-2Y-0PAP-1Y-0B \\
Llareta INIA & (D67.54.4a.9A//Jori 'S' × Rosner Durum 119-200-4Y) Sahel 77 & CD 64399-4p-2p-3p \\
Camayo & Eth-Lrbr A1-133/3*Altar 84 & CDSP91B931-A-1H-030Y-030M-3Y-0M-1Y-0B \\
Storlom & Sitella/3 Musk_4 & CD91Y1719-B-11Y-040M-030Y-2M-1Y-0B \\
Guayacan 2 & Altar 84/Stint//Silver_45 & CD80545-A-1Y-030YRC-040M-2YRC-0PAP \\
Guayacan INIA & Altar 84/Stint//Silver & CD80545-A-1Y-030YRC-049M-3YRC-0PAP \\
Atil C2000 & Sooty_9/Rascon_37 & CD91B1938-6M-030Y-030M-4Y-0M-0B-1Y-0B \\
\hline
\end{tabular}

${ }^{a}$ Consists of the cross number and selection identification in different segregating generations. 
acan 2, and Guayacan INIA had trace (1\%) severity with resistant or moderately resistant reactions; and Camayo displayed 5 to $10 \%$ rust with a resistant reaction (Table 2).

Responses of $F_{1}$ plants of susceptible $x$ resistant crosses. In the greenhouse tests, the $F_{1}$ adult plants produced by crossing Atil C2000 with Jupare C2001, Hualita, and Pohowera, respectively, displayed susceptible infection type $3+$, indicating that the resistance was recessive (Table 2). The infection types of $F_{1}$ plants produced by crossing Atil C2000 with Camayo and Storlom, respectively, were very similar to the infection types of their respective parents, indicating that the resistance was dominant. In contrast, the infection types displayed by $F_{1}$ plants of the remaining four crosses were higher than those displayed by the respective parents, but not compatible, indicating the partially dominant nature of the resistance.

In the field trial, responses of $F_{1}$ plants ranged from 0 to $60 \mathrm{MS}$ compared with the $100 \mathrm{~S}$ response of the susceptible parent Atil C2000, indicating that resistance was either dominant or partially dominant (Table 2). Field results were thus different from greenhouse results for several crosses. Only Somateria and Llareta INIA displayed $F_{1}$ responses similar to those of the resistant parents, indicating that the resistance was dominant. Rust severities and reactions of the $F_{1}$ plants of the remaining seven crosses were higher than those of their respective resistant parents, indicating that the resistance was partially dominant.

$F_{2}$ and $F_{3}$ segregation in susceptible $x$ resistant crosses. The $F_{2}$ populations from crosses of susceptible Atil C2000 with resistant Jupare C2001, Hualita, Pohowera, Guayacan 2, and Guayacan INIA, respectively, had a greater number of susceptible plants than expected for segregation of a single dominant or partially dominant resistance gene (Table 3). The frequencies of resistant and susceptible plants in the crosses involving Jupare C2001, Pohowera, Guayacan 2, and Guayacan INIA as resistant parents conformed to a 9:7 ratio $(P \geq 0.05)$, which is as expected for the segregation of two dominant-partially dominant complementary genes. In the cross with Hualita as the resistant parent, the segregation conformed to a 7:9 ratio, indicating the presence of two recessive genes. Distributions of homozygous resistant (HR), segregating (Seg), and homozygous susceptible (HS) $F_{3}$ lines in Jupare C2001 and Pohowera crosses were in ac- cordance with a 1:8:7 ratio, further supporting the hypothesis that two complementary genes conferred resistance. Also, the $\mathrm{F}_{3}$ lines in the cross involving Hualita were distributed in accordance with a 1:8:7 ratio, indicating the presence of two complementary genes. The $\mathrm{F}_{3}$ distributions for crosses involving Guayacan 2 and Guayacan INIA showed a better fit with a 1:2:1 ratio, which is as expected for segregation of a single resistance gene, although the $P$ value in the $\chi^{2}$ test for the latter cross was only 0.02 .

The $F_{2}$ populations originating from crosses involving Atil C2000 as the susceptible parent and Somateria, Llareta INIA, Camayo, and Storlom as the resistant parents segregated according to a $3: 1$ ratio $(P \geq 0.05)$, indicating that a single dominant gene conferred resistance (Table $3)$. Distributions of $F_{3}$ lines in each cross were also in agreement with $F_{2}$ results; however, for the Somateria cross, the $P$ value in the $\chi^{2}$ test was 0.02 due to a higher number of segregating $\mathrm{F}_{3}$ lines.

Intercrosses among resistant parents. All $F_{1}$ plants from the resistant $\times$ resistant crosses were resistant in the field trial (Table 4). Only five of the 36 intercrosses displayed rust severities higher than $0 \%$. This indicated that $F_{1}$ plants usually fol-

Table 3. Frequencies of resistant and susceptible $F_{2}$ plants; and distributions of homozygous resistant, segregating, and homozygous susceptible $F_{3}$ families in crosses of susceptible parent Atil C2000 with nine resistant Triticum turgidum parents when tested in the field with Puccinia triticina race BBG/BN

\begin{tabular}{|c|c|c|c|c|c|c|c|c|c|}
\hline \multirow[b]{2}{*}{ Resistant parent } & \multicolumn{4}{|c|}{ Number of $F_{2}$ plants } & \multicolumn{5}{|c|}{ Number of $F_{3}$ lines } \\
\hline & $\mathbf{R}^{\mathbf{a}}$ & $\mathbf{S}^{\mathbf{b}}$ & Exp. ratio & $P$ value for $\chi^{2}$ & HR $^{\mathrm{c}}$ & Segd $^{d}$ & $\mathbf{H S}^{\mathbf{e}}$ & Exp. ratio & $P$ value for $\chi^{2}$ \\
\hline Jupare C2001 & 124 & 100 & $9: 7$ & 0.79 & 5 & 45 & 48 & $1: 8: 7$ & 0.56 \\
\hline Hualita & 72 & 123 & $7: 9$ & 0.05 & 9 & 37 & 31 & $1: 8: 7$ & 0.14 \\
\hline Pohowera & 139 & 115 & $9: 7$ & 0.62 & 5 & 49 & 42 & $1: 8: 7$ & 0.91 \\
\hline Somateria & 148 & 55 & $3: 1$ & 0.49 & 15 & 62 & 21 & $1: 2: 1$ & 0.02 \\
\hline Llareta INIA & 170 & 52 & $3: 1$ & 0.59 & 25 & 48 & 25 & $1: 2: 1$ & 0.98 \\
\hline Camayo & 128 & 41 & $3: 1$ & 0.82 & 20 & 48 & 30 & $1: 2: 1$ & 0.35 \\
\hline Storlom & 207 & 62 & $3: 1$ & 0.46 & 32 & 41 & 19 & $1: 2: 1$ & 0.09 \\
\hline Guayacan 2 & 136 & 105 & $9: 7$ & 0.95 & 13 & 51 & 24 & $1: 2: 1$ & 0.08 \\
\hline Guayacan INIA & 125 & 99 & $9: 7$ & 0.89 & 33 & 51 & 14 & $1: 2: 1$ & 0.02 \\
\hline
\end{tabular}

Table 4. Reactions of $F_{1}$ plants for intercrosses among parents (right diagonal) and frequencies of resistant-susceptible $F_{2}$ plants (left diagonal) when evaluated in the field with Puccinia triticina race BBG/BN

\begin{tabular}{|c|c|c|c|c|c|c|c|c|c|}
\hline \multirow[b]{2}{*}{$\begin{array}{l}\text { Number of } \\
F_{2} \text { plants }\end{array}$} & \multicolumn{9}{|c|}{$F_{1}$ reaction $^{\mathrm{a}}$} \\
\hline & $\begin{array}{l}\text { Jupare } \\
\text { C2001 } \\
\end{array}$ & Hualita & Pohowera & Somateria & $\begin{array}{c}\text { Llareta } \\
\text { INIA }\end{array}$ & Camayo & Storlom & Guayacan 2 & $\begin{array}{c}\text { Guayacan } \\
\text { INIA }\end{array}$ \\
\hline Jupare C2001 & & 0 & 0 & 0 & 0 & 0 & 0 & 0 & 0 \\
\hline Hualita & $205 / 0$ & & 0 & 0 & 0 & 0 & 0 & 0 & $1 \mathrm{MR}$ \\
\hline Pohowera & $210 / 0$ & $206 / 0$ & & 0 & 0 & 0 & 0 & 0 & 0 \\
\hline Somateria & $136 / 29$ & $204 / 28$ & $243 / 23$ & & 0 & 0 & 0 & 0 & 0 \\
\hline Llareta INIA & $177 / 6$ & $209 / 14$ & $206 / 12$ & $248 / 0$ & & 0 & 0 & 0 & 0 \\
\hline Camayo & $139 / 20$ & $209 / 20$ & $234 / 12$ & $187 / 35$ & $178 / 27$ & & 0 & $40 \mathrm{MR}$ & $50 \mathrm{MR}$ \\
\hline Storlom & $167 / 17$ & $224 / 15$ & $150 / 11$ & $183 / 10$ & $202 / 20$ & $198 / 0^{\mathrm{b}}$ & & $15 \mathrm{MR}$ & $10 \mathrm{MR}$ \\
\hline Guayacan 2 & $190 / 32$ & $204 / 30$ & $140 / 19$ & $196 / 35$ & $144 / 25$ & $206 / 27$ & $218 / 34$ & & 0 \\
\hline Guayacan INIA & $152 / 35$ & $187 / 33$ & $206 / 22$ & $169 / 41$ & $160 / 32$ & $223 / 40$ & $211 / 44$ & $195 / 0$ & \\
\hline
\end{tabular}

${ }^{a}$ Field disease ratings have two components: disease severity and host response to infection. Severity follows the modified Cobb scale (12), and host response to infection are $\mathrm{R}=$ resistant, $\mathrm{MR}=$ moderately resistant, $\mathrm{MS}=$ moderately susceptible, and $\mathrm{S}=$ susceptible (17).

${ }^{\mathrm{b}}$ Fully susceptible plants were absent, but plants with higher disease ratings than expected for either parents or their $\mathrm{F}_{1}$ were present. 
lowed the response of the parent with a higher resistance level. Exceptions were $F_{1}$ plants from Guayacan INIA $\times$ Hualita, which displayed responses similar to that of the less resistant parent Guayacan INIA instead of the more resistant parent Hualita. For four crosses, Camayo $\times$ Guayacan 2, Camayo $\times$ Guayacan INIA, Guayacan $2 \times$ Storlom, and Guayacan INIA $\times$ Storlom, the $F_{1}$ plants displayed more susceptible responses than those of their respective parents.

The $\mathrm{F}_{2}$ field segregation data for the intercrosses indicated that several parents carry common resistance genes due to the lack of susceptible plants in their progeny (Table 4). All $\mathrm{F}_{2}$ plants were immune $(0 \%$ rust) in intercrosses among Jupare C2001, Hualita, and Pohowera, indicating that they carried the same pair of complementary resistance genes. Similarly, all $\mathrm{F}_{2}$ plants of the Somateria $\times$ Llareta INIA cross showed immunity or trace severity with resistant reaction. The Guayacan $2 \times$ Guayacan INIA cross also failed to segregate. Although segregation was observed in the Camayo $\times$ Storlom cross, completely susceptible progeny were absent in a population of 198 plants, 135 of which displayed a $0-1 \mathrm{R}$ response, 43 scored 5-15MR, 9 scored 30M, 7 scored 50M, 1 scored 60 MS, and 3 scored 70 MS. Several susceptible plants were found in the remaining crosses.

\section{DISCUSSION}

We have identified five different sources of resistance to $P$. triticina race $\mathrm{BBG} / \mathrm{BN}$ among nine CIMMYT durum wheat parents included in the study. Resistance in Jupare C2001, Hualita, and Pohowera was controlled by the same two partially dominant complementary genes (source 1), while the resistance in Somateria and Llareta INIA was determined by the same single dominant gene (source 2). A single partially dominant gene was found to confer resistance in Camayo (source 3) and another partially dominant gene in Storlom (source 4); however, these two genes seem to be closely linked. A different partially dominant gene was present in sister selections Guayacan 2 and Guayacan INIA (source 5).

Hualita displayed infection type $\mathrm{X}$ - in adult plant greenhouse tests, which was somewhat higher than the infection type ;1- displayed by Jupare C2001 and Pohowera, belonging to the same source (Table 2). The seedling infection types and field reactions of all three were the same. The variation observed in adult plant greenhouse trials may therefore be due to the effect of genetic background. The $F_{1}$ plants from the crosses of these three durums with susceptible parent Atil C2000 were scored as susceptible in the greenhouse, but resistant in the field. It must be noted that $F_{1}$ plants involving Jupare C2001 showed higher disease responses in the field than $F_{1}$ plants involving the other two durums. This indicated that the recessive or dominant nature of resistance or the expression of resistance may change depending on test conditions and genetic background. We have repeatedly observed that leaf rust resistance in durum wheat expresses better under field conditions than in seedling or adult plant greenhouse tests. We have also attempted to classify $F_{2}$ populations in the greenhouse, but have had difficulty distinguishing plants with slight resistance from those showing susceptibility. The distribution of $F_{3}$ lines for Atil C2000 $\times$ Hualita was in accordance with the segregation expected for two dominant complementary genes, despite the fact that the $F_{2}$ segregation conformed to a 7:9 ratio for segregation of two recessive genes. However, the presence of two recessive genes cannot be supported because the $F_{1}$ plants were resistant in the field.

Complementary genes with dominant interaction conditioning rust resistance are not known to occur in durum wheat. In fact, complementary gene interaction determining resistance to the wheat rusts is rare. The only identified and designated complementary leaf rust resistance genes are Lr27 and Lr31 (24,25). Gene Lr31 is either completely linked or the same as LrI2 (18). Genes $L r 27$ and Lr31, originally found in bread wheat, have been located on chromosomes $3 \mathrm{BS}$ and $4 \mathrm{BL}$, respectively $(10,25)$. The infection type response of bread wheat cultivar Gatcher carrying Lr27 and Lr31 is $\mathrm{X}-$ and ; when tested at 20 to $23^{\circ} \mathrm{C}$ and 15 to $18^{\circ} \mathrm{C}$, respectively, at the seedling stage with race BBG/BN (23). Since the three durums (Jupare C2001, Hualita, and Pohowera) carrying complementary resistance genes displayed infection types similar to that of Gatcher, at least at higher temperatures, it may be argued that the complementary resistance in durum wheat could involve the same complementary genes present in Gatcher. Gene $L r 27$ is closely linked to stem rust resistance gene $S r 2$ (24), originally identified in T. turgidum var. dicoccum (emmer wheat) cv. Yaroslav and later transferred to hexaploid wheat (7). Gene $\mathrm{Sr} 2$, also associated with pseudo-black chaff and seedling chlorosis, is not known to occur in CIMMYT durum wheat germ plasm. Lr27 is present but $S r 2$ absent in a few hexaploid wheat cultivars: Timgalen (Australia), Jupateco 73S and Opata 85 (Mexico), plus Chinese Spring (Ciano 3B), a chromosome substitution line $(8,24)$. Stem rust resistance gene $\mathrm{Srl} 12$ is located on the same chromosome arm (3BS) as $\operatorname{Lr} 27$ but is genetically independent and common in CIMMYT durum wheat germ plasm (21). Whether the complementary resistance genes in durum are the same as $L r 27$ and Lr31 could be determined either by mapping them onto wheat chromosomes using molecular markers or by developing a synthetic hexaploid wheat using a susceptible $T$. tauschii accession and then conducting the allelism test with tester lines such as Gatcher.

It should also be pointed out that the segregation of 9 resistant: 7 susceptible in the $\mathrm{F}_{2}$, and the distribution of 1HR: 8Seg: 7HS in the $\mathrm{F}_{3}$ families fit the expected ratios, not only for two complementary genes, but also for a dominant resistance gene together with a recessive suppressor gene. Genes suppressing rust resistance have been reported previously in the wheat rust system. Bai and Knott (2) found evidence of several suppressors of leaf rust resistance in the D-genome of bread wheat. In hexaploid synthetic wheat, Nelson et al. (10) identified a suppressor gene (SuLr23) derived from T. tauschii on chromosome arm 2DS that suppressed gene $\operatorname{Lr} 23$ located at the orthologous position on chromosome $2 \mathrm{BS}$ in durum wheat. Knott (6) found suppressors in the A and B genomes of durum wheat Medea for stem rust resistance genes; Assefa and Fehrman (1) also indicated the presence of genes suppressing leaf rust resistance in the A and/or B genomes of durum wheat.

According to segregation results, Llareta INIA and Somateria carry the same dominant gene (resistance source 2). The seedling and adult plant responses of these two durums were comparable to those belonging to source 1 (Table 2). Cross Atil C2000 $\times$ Llareta INIA fit the hypothesis of one dominant gene in the $\mathrm{F}_{3}$ generation better than did cross Atil C2000 $\times$ Somateria.

Greenhouse infection type responses and field ratings of resistance sources 3 and 4 were quite different. Camayo displayed infection types $1+$ at seedling and $3 \mathrm{C}$ at adult plant stage, whereas Storlom was highly resistant, with infection types ; at seedling and 0; at adult plant stage. Different temperatures and light conditions could have caused somewhat higher infection types in adult plants of Camayo in the greenhouse, as the tests were not carried out together. In the field, Camayo displayed a 5-10R response, while Storlom showed immunity (Table 2). Although completely susceptible recombinants were not found in the $F_{2}$ population from the intercross of these two durums, we infer that the two parents carry different but closely linked resistance genes in repulsion. Assuming that the two resistance genes are not linked, approximately 12 completely susceptible plants (1/16) should have occurred in the $\mathrm{F}_{2}$ population of the 198 evaluated plants. If a complete repulsion genetic linkage is assumed, the conformation of the $\mathrm{F}_{2}$ progeny will be 1AAbb: 2 AaBb: 1aaBB. Considering the response of both parents $(0 \%$ for Storlom and 5-10MR for Camayo) and the response of the $\mathrm{F}_{1}$ of the intercross $(0 \%)$, all the plants should then have been resistant, with $75 \%$ of them showing no disease and $25 \%$ with $5-10 \mathrm{MR}$ reactions. This was not 
the case, since $20 \mathrm{~F}_{2}$ plants displayed $30 \mathrm{M}$ $70 \mathrm{MS}$ reactions, indicating that the two genes were not alleles at the same locus. The likelihood of obtaining recombinants with higher responses depends on the recombination frequency (crossing-over) between the two genes. Considering the response of the parents, 0 and 5 to $10 \%$, and the response of the $F_{1}$ plants, $0 \%$, we may assume that plants with response 0 to $1 \%$ (i.e., a total of 135 plants among the 198) have genotypes $\mathrm{AAB}_{-}$and $\mathrm{AaB}_{-}$. These genotypes, parental and recombinant, cannot be distinguished from each other because they are probably showing the same immune response in the field. Forty-three plants had 5-15MR field response, similar to the reaction of the resistant parent Camayo, and therefore probably belong to genotype aaBB. Because $F_{1}$ plants from crosses of susceptible parent Atil C2000 with Storlom and Camayo displayed $20 \mathrm{M}$ and $50 \mathrm{M}$ reactions, respectively, it can be assumed that the nine $F_{2}$ plants showing a $30 \mathrm{M}$ response and the 11 plants whose response ranged from $50 \mathrm{M}$ to $70 \mathrm{MS}$ represent genotypes Aabb and aaBb. In a total of 20 plants, genotypes Aabb and $\mathrm{aaBb}$ are the only recombinants that can be distinguished. Recombinant aabb was absent, as no totally susceptible plant was found. Since we know that the total number of Aabb, aaBb, and aabb recombinants is 20 plants, it can be assumed that the total number of $\mathrm{AABB}, \mathrm{AABb}$, and $\mathrm{AaBB}$ recombinants is also the same. Thus, the total number of recombinants would be 40 out of 198 evaluated plants. Therefore, the recombination frequency would be approximately $20 \%$. This estimate should be confirmed by studying segregation in the $\mathrm{F}_{3}$ generation. Only in this way can the different genotypes giving immune leaf rust response in the $\mathrm{F}_{2}$ generation be distinguished.

Another partially dominant resistance gene was found in the two durums belonging to resistance source 5. Guayacan 2 and Guayacan INIA are sister selections from the same cross and, hence, likely to carry the same resistance gene. This hypothesis is strongly supported by the following: (i) both parents and the $\mathrm{F}_{1}$ plants from crosses with susceptible parent Atil C2000 displayed similar greenhouse and field reactions (Table 2); (ii) no segregation was observed in the $F_{2}$ when the two resistant parents were crossed (Table 4); and (iii) $\mathrm{F}_{1}$ plants displayed intermediate, but similar, reactions when both parents were crossed with Camayo and Storlom (Table 4). The $\mathrm{F}_{2}$ segregation for crosses Atil C2000 $\times$ Guayacan 2 and Atil C2000 × Guayacan INIA conformed to a 9:7 segregation ratio. The $F_{3}$ segregations for both crosses indicated, however, that resistance was due to a single gene, despite the fact that the $P$ value for $\chi^{2}$ test for the Guayacan INIA cross was only 0.02 (Table 3 ). The lower $P$ value of this cross is because a smaller number of $\mathrm{F}_{3}$ lines scored as $\mathrm{HS}$ and an excess of lines scored as HR. This situation could in no way have been caused by the presence of two complementary genes. Because the $F_{1}$ plants from these crosses were rated as $50 \mathrm{MS}$ and $60 \mathrm{MS}$, it is possible that we misclassified some heterozygous $\mathrm{F}_{2}$ plants into the susceptible group. When the $\mathrm{F}_{3}$ segregation data for the two crosses (Atil C2000 $\times$ Guayacan 2 and Atil C2000 $\times$ Guayacan INIA) were pooled, the $\chi^{2}$ test for segregation of a single resistance gene gave a $P$ value of 0.30 .

Dominant and recessive genes for leaf rust resistance have previously been reported in durum wheat $(3,4,9,16,22,26-$ 28 ). However, only a few of the designated genes were originally derived from durum (LrI4a and Lr23), and only a few known designated genes have been reported to be present in durum wheat. In addition to Lr14a, which is effective against Mexican $P$. triticina race $\mathrm{BBG} / \mathrm{BN}$, other effective leaf rust resistance genes reported in durum wheat are $\operatorname{Lr3}, \operatorname{Lrl3}$ (19), Lrl6 (27), and $\operatorname{Lrll}$ (27), but further studies are required to confirm if any of these genes are present in the durum wheats included in this study. Nonetheless, it is worth mentioning that some of the present durum wheat lines, such as Jupare C2001, Hualita, and Storlom, are known to have bread wheat in their pedigrees. Further mapping studies will also be required to determine whether the five sources of resistance identified in our study correspond to any previously designated genes or are new genes specifically present in durum wheat.

These resistance genes confer a high level of protection against the new $P$. triticina race $\mathrm{BBG} / \mathrm{BN}$ that currently predominates in durum wheat growing areas of Mexico and could therefore be used in breeding to enhance genetic diversity. These genes could also be useful to breeding programs in countries where leaf rust races attacking durum wheats have similar virulence specificity. However, to enhance their life span, these genes must be used in combinations. Identification of DNA markers closely linked to each resistance gene could help to locate these genes in the genome, to understand the relationship between leaf rust resistance genes in durum and bread wheat, and to pyramid these genes for long-term control of the disease.

\section{ACKNOWLEDGMENTS}

We appreciate the financial support of the Swedish Agency for Research Cooperation with Developing Countries (SIDA-SAREC) and CIMMYT, and we also acknowledge the technical editing provided by A. McNab.

\section{LITERATURE CITED}

1. Assefa, S., and Fehrman, H. 2000. Resistance to wheat leaf rust in Aegilops tauschii Coss. and inheritance of resistance in hexaploid wheat. Genet. Resour. Crop Evol. 47:135-140.

2. Bai, D., and Knott, D. R. 1992. Suppression of rust resistance in bread wheat (Triticum aesti- vum L.) by D-genome chromosomes. Genome 35:276-282.

3. Gupta, S., Gupta, A. K., and Saini, R. G. 1992. Inheritance of resistance to leaf rust (Puccinia recondita f. sp. tritici) in two durum wheats. Wheat Inf. Serv. 75:41-45.

4. Gupta, S., Saini, R. G., and Gupta, A. K. 1995. Genetic analysis of resistance to leaf rust (Puccinia recondita $\mathrm{f}$. sp. tritici) pathotypes in the durum wheats 'PBW 34' and 'DWL 5023'. Plant Breed. 114:176-178.

5. Huerta-Espino, J., and Roelfs, A. P. 1992. Leaf rust on durum wheats. Vortr. Pflanzenzuchtg. 24:100-102.

6. Knott, D. R. 2000. Inheritance of resistance to stem rust in Medea Durum wheat and the role of suppressors. Crop Sci. 40:98-102.

7. McFadden, E. S. 1930. A successful transfer of emmer characters to vulgare wheat. J. Am. Soc. Agron. 22(12):1020-1034.

8. McIntosh, R. A., Wellings, C. R., and Park, R. F. 1995. Wheat rusts: An atlas of resistance genes. CSIRO, Australia.

9. Mishra, N. A. 1996. Genetics of leaf rust resistance in durum wheat. Ph.D. thesis. University of Minnesota, St. Paul.

10. Nelson, J. C., Singh, R. P., Autrique, J. E., and Sorrells, M. E. 1997. Mapping genes conferring and suppressing leaf rust resistance in wheat. Crop Sci. 37:1928-1935.

11. Ordonez, M. E., Kolmer, J. A., and Groth, J. V. 2004. Virulence specificities of Puccinia triticina (leaf rust) from durum wheat from world-wide collections. Proc. Int. Cereal Rusts Powdery Mildews Conf., 11th. Abstr. 1.49, Cereal Rusts Powdery Mildews Bull. Published online.

12. Peterson, R. F., Campbell, A. B., and Hannah, A. E. 1948. A diagrammatic scale for estimating rust intensity of leaves and stem of cereals. Can. J. Res. Sect. C 26:496-500.

13. Pingali, P. L., ed. 1999. CIMMYT 1998-99 World Wheat Facts and Trends. Global Wheat Research in a Changing World: Challenges and Achievements. CIMMYT, Mexico, D. F.

14. Ramirez-A, I., Cortazar, S. R., Hacke, E. E., Granger, Z. D., and Zerene Z. M. 1997. Guayacan INIA, variedad de trigo candeal Triticum turgidum var. durum para la zona central de Chile. Agric. Téc. 57(3):209-211.

15. Ramirez-A, I., Cortazar, S. R., Hacke, E. E. Granger, Z. D., and Zerene, Z. M. 1997. Llareta INIA, variedad de trigo candeal Triticum turgidum var. durum para la zona central de Chile. Agric. Téc. 57(3):212-214.

16. Rashid, G., Quick, J. S., and Statler, G. D. 1976. Inheritance of leaf rust in three durum wheats. Crop Sci. 16:294-296.

17. Roelfs, A. P., Singh, R. P., and Saari, E. E. 1992. Rust Diseases of Wheat: Concepts and Methods of Disease Management. CIMMYT, Mexico, D. F

18. Singh, D., Park, R. F., and McIntosh, R. A. 1999. Genetic relationship between the adult plant resistance gene Lr12 and the complementary gene $L r 31$ for seedling resistance to leaf rust in common wheat. Plant Pathol. 48:567-573.

19. Singh, H., Dhaliwal, H. S., and Gill, K. S. 1992. Diversity for leaf rust resistance in Triticum durum germplasm. Cereal Rusts Powdery Mildews Bull. 20(1\&2):62-67.

20. Singh, R. P. 1991. Pathogenicity variations of Puccinia recondita f. sp. tritici and $P$. graminis f. sp. tritici in wheat-growing areas of Mexico during 1988 and 1989. Plant Dis. 75:790-794.

21. Singh, R. P., Bechere, E., and Abdalla, O 1992. Genetic analysis of resistance to stem rust in ten durum wheats. Phytopathology 82:919-922.

22. Singh, R. P., Bechere, E., and Abdalla, O. 1993. Genetic analysis of resistance to leaf rust in nine durum wheats. Plant Dis. 77:460-463. 
23. Singh, R. P., Huerta-Espino, J., Pfeiffer, W., and Figueroa-Lopez, P. 2004. Occurrence and impact of a new leaf rust race on durum wheat in northwestern Mexico from 2001 to 2003. Plant Dis. 88:703-708.

24. Singh, R. P., and McIntosh, R. A. 1984. Complementary genes for reaction to Puccinia recondita tritici in Triticum aestivum. I. Genetic and linkage studies. Can. J. Genet. Cytol. 26:723-735.

25. Singh, R. P., and McIntosh, R. A. 1984. Complementary genes for reaction to Puccinia recondita tritici in Triticum aestivum. II. Cytogenetic studies. Can. J. Genet. Cytol. 26:736742.

26. Statler, G. D. 1973. Inheritance of leaf rust resistance in Leeds durum wheat. Crop Sci. 13:116-117

27. Zhang, H., and Knott, D. R. 1990. Inheritance of leaf rust resistance in durum wheat. Crop Sci. 30:1218-1222.

28. Zhang, H., and Knott, D. R. 1993. Inheritance of adult plant resistance to leaf rust in six durum wheat cultivars. Crop Sci. 33:694-697. 